\title{
A Review on Biodegradable Films
}

\author{
Aashima $^{1}$, Prerna Singh ${ }^{1}$ and Anshu Sibbal Chatli ${ }^{2 *}$
}

${ }^{1}$ Department of Biotechnology, ${ }^{2}$ Department of Microbiology, Guru Nanak Girls College Model Town, Ludhiana (Punjab), India

*Corresponding author

\section{Keywords}

Biodegradable films, Starch, Essential oils

\section{Article Info}

Accepted:

26 April 2020

Available Online:

10 May 2020

\section{A B S T R A C T}

In Today's scenario, various food industries use harmful packaging materials like plastics, metal, paper and combination of more than one material or composites. Approximately, $60 \%$ of plastics are being used in packaging and almost half of that is used to pack food-products, which is very dangerous for human health. Plastic is non-biodegradable and is not safe for food packaging and causes various health hazards. Plastic also reduces moisture and oxygen transfer rate of soil and deteriorates the quality of soil. To get over this problem, there is an urgent need to develop packaging films, which is biodegradable and safe for food packaging. Starch based edible films are biodegradable and also increase the shelf life of food products if incorporated with essential oils.

\section{Introduction}

Food packaging is concerned with the preservation and protection of foods and their raw materials, particularly from oxidative and microbial spoilage and also extends their shelf-life. Biodegradable films degrade naturally. Among all the natural polymers, starch has been considered as one of the most promising candidate for future material, because of its attractive combination of price, abundance and renewable in addition to biodegradability. All the plant seeds and tubers contain starch, which is predominantly present as amylose and amylopectin. Foods that are high in starch include bread, grains, cereals, rice, potato, peas, corn etc. Starch exhibits thermoplastic behaviour (Choi et al., 2007).

The essential oils like cinnamaldehyde, lemongrass oil, clove oil, peppermint oil etc are traditionally being used in food and medicines due to their antimicrobial effects. Cinnamaldehyde is also used as fungicide (Aliabadi et al., 2017). Clove oil is effective against Escherichia coli, Salmonella typhimurium, Staphylococcus aureus and 
Listeria monocytogens (Bharath et al., 2017). Lemongrass oil is used as aromatherapy to relieve muscle pain, externally to kill bacteria etc. Lemongrass oil is effective against Aeromonasveronii, Enterococcus faecalis, Salmonella enteri etc. Gram positive organisms are more sensitive to lemongrass oil as compared to Gram negative bacteria (Naik et al., 2010). Antimicrobial activity of peppermint oil against some Gram positive and Gram negative bacteria is explained by Singh et al., 2015.

The biodegradable packaging films with antimicrobial properties can be developed with the addition of these essential oils. The developed antimicrobial films can be used to enhance the storage stability of different perishable foods.

\section{Biodegradable films}

Researchers, drug and food industries have shown great interest in the development of biodegradable films since 1980s due to the fact that it can substitute traditional plastic films. These biodegradable films not only enhance the quality of food but also act as barrier for gas, moisture and provide protection to food product after primary package is opened (Kim and Ustunol, 2001).

Various sources can be used in the production of biodegradable films like polysaccharides, proteins, lipids or combination of these. Among these, protein based biodegradable films are found to be attractive with better mechanical and gas barrier properties as compared to lipids and polysaccharides $(\mathrm{Ou}$ et al., 2004).

\section{Polysaccharide films}

Polysaccharides such as cellulose, chitosan, starch, pectin and alginate are used to form films with good barrier properties against gases such as oxygen and carbon dioxide. Starch is one of the promising raw materials for the production of biodegradable plastics because of its low cost, its availability as a renewable resource and also its degradation products are innocuous (Mollah et al., 2016). The tensile strength values of starch/chitosan based films were comparable to high-density polyethylene films (Cazon et al., 2017). Chitosan has also been extensively used in films due to its ability to inhibit the bacterial and fungal pathogens growth as it interferes with the negatively charged residues of macromolecules exposed on the fungal cell surface and changes the permeability of the plasma membrane (Romanazzi et al., 2002). Addition of fatty acids was found to be effective in enhancing the antimicrobial properties of chitosan (Dos santos et al., 2012).

Dias et al., (2010) formulated biodegradable films from rice starch, rice flour and characterized their physicochemical, microscopic and mechanical properties. Films from rice starch and rice flour were prepared by casting with glycerol or sorbitol as plasticizer. Scanning electron microscope analysis of starch and flour films revealed compact structures and had comparable mechanical properties. However, water vapour permeabilities were two times higher for rice flour films than those of starch based films. Films with sorbitol were less permeable to water and more rigid while films with glycerol are more plasticized and have poorer water vapour barrier properties. Mollah et al., (2016) formulated biodegradable starch-based chitosan reinforced composite polymeric films by casting. The chitosan content in the films varied from $20 \%$ to $80 \%$ (w/w).

Tensile strength was improved significantly with the addition of chitosan but elongation at break of the composites decreased. Tensile strength of the composites raised more with 
the addition of the Acacia catechu content in the films that varied from $0.05 \%$ to $0.2 \%$ (w/w). The better thermal stability of this prepared film was confirmed by thermogravimetric analysis.

Surface morphologies of the composites were examined by scanning electron microscope suggested sufficient homogenization of starch, chitosan and Acacia catechu. Water uptake was found lower for final composites in comparison to starch/chitosan and chitosan films. The developed films intended to use as the alternative of synthetic non-biodegradable coloured packaging films.

\section{Lipid films}

The efficiency of lipid materials in film formation depends on the nature of the lipid used, its structure, chemical arrangement, hydrophobicity, physical state, and lipid interactions with the other components of the film (Rhim and Shellhammer, 2005). Lipids are usually combined with other film-forming materials such as proteins or polysaccharides as emulsion particles or multilayer coatings in order to increase the resistance to water penetration (Mehyar et al., 2012).

Polar resin films are good barriers for $\mathrm{O}_{2}$, $\mathrm{CO}_{2}$ and ethylene. Hydrophobic substances used for the lipid-based films include natural waxes (carnauba, rice bran and beeswax); petroleum-based waxes (paraffin and polyethylene wax); petroleum-based mineral and vegetable oils (Rhim and Shellhammer, 2005). Wax is the term used for a series of naturally or synthetically produced non-polar substances. Waxes are the efficient barriers to water-vapour transfer due to their hydrophobic nature (Han, 2003).

\section{Protein films}

Protein based edible films have received considerable attention in the recent years due to their ability to be used as edible packaging materials over the synthetic films (Wittaya, 2012). Proteins are superior to other sources like polysaccharide due to their ability to form films with greater mechanical and barrier properties (Cuq et al., 1998). Protein based films are being used as carriers for antimicrobial and antioxidant agents.

Antimicrobial packaging is an emerging technology that could have a significant impact on shelf life extension and food safety. Use of antimicrobial agents in food packaging can control the microbial population and target specific microorganisms to provide higher safety and quality products (PerezPerez et al., 2006). Protein based films are being used in multilayer food packaging materials together with non-edible films. In this case, the protein based edible films would be the internal layers in direct contact with food materials.

The protein films are generally formed from solutions or dispersions of the protein as the solvent (water, ethanol or mixture) evaporates (Kester and Fennema, 1986). Proteins must be denatured by heat, acid, base and solvent in order to form more extended structures that are required for film formation.

The extended protein chains can associate through hydrogen, ionic, hydrophobic and covalent bonding. Thus protein films are expected to be good oxygen barriers at low relative humidities. Various types of proteins like whey protein, corn Zein, wheat gluten, soy protein, mung bean protein, and peanut protein have been used for film formation (Bourtoom, 2008). Zein has excellent film forming properties and is used for fabrication of biodegradable films.

Su et al., (2007) formulated edible protein films from soy protein isolate through an enzymatic cross-linking method with a purified microbial transglutaminase (MTG) 
that was produced from a new effective strain Streptomyces sp. WZFF.L-M1 which was followed by addition of glycerol and suitable heating and drying treatments.

The films were about $50 \mathrm{~mm}$ thin, had homogenous structures without any observable holes. The films had high water keeping capacity and strong elasticity that the ultimate tensile strength (TS) and elongation at break $(\mathrm{Eb})$ had been increased $(\mathrm{TS}>5 \mathrm{MPa}$, $\mathrm{Eb}>50 \%)$ and that the prevention rates against the permeability of water vapour and oxygen were also upgraded more than $85 \%$ and $70 \%$, respectively.

Wagh et al., (2014) formulated casein and whey protein concentrate (WPC) films plasticized with glycerol and sorbitol. Tensile strength (TS), tensile strain (TE) and elastic modulus (EM) of the films ranged from 0.71 to $4.58 \mathrm{MPa}, 19.22$ to $66.63 \%$ and 2.05 to $6.93 \mathrm{MPa}$, respectively. The film properties were influenced by the type of biopolymer (casein and whey protein concentrate), plasticizer and its concentration. The increase in the level of the plasticizer, increased the film thickness, TE and water vapour permeability (WVP), however decreased TS and EM. Casein films showed superior tensile properties as compared to WPC films. The oxygen permeability of casein films was relatively lower than that of WPC films, regardless of the plasticizer used.

Nandane et al., (2015) studied the effect of process parameters on mechanical properties of Soy protein Isolate (SPI) edible film using response surface methodology. The increase in level of SPI increases thickness and tensile strength whereas decrease in young's modulus and elongation at break. Increase in amount of plasticizer, decreased thickness and tensile strength but increased young's modulus and elongation at break. The optimum formulation for meeting the set criteria of response functions was SPI concentration $8.65 \%$, plasticizer concentration $60 \%$, and $\mathrm{pH} 8.99$.

\section{Bioactive biodegradable packaging}

It is defined as the packaging in which the material used is biodegradable like cellophane and the functional additive is of natural origin like nisin (Guerra et al., 2005). According to Lopez-Rubio et al., (2006), bioactive packaging is a way to create healthier packaged foods which have a direct beneficial impact on consumer's health. Bioactive compounds are defined as essential and nonessential compounds that occur in nature and are part of the food chain with some health benefits (Biesalski et al., 2009). The types of bioactive compounds that have been proposed or used in food packaging include enzymes, peptides, polysaccharides, phospholipid analogs, antibodies, oligonucleotides and other antimicrobial agents (Goddard and Hotchkiss, 2007).

Ko et al., (2001) studied the effects of hydrophobicity/ hydrophilicity of edible films against Listeria monocytogenes strain V7 by various nisin concentrations (4.0 - 160 IU/film disk) and $\mathrm{pH}$ values ranging from 2.0 to 8.0. Mechanical properties and water vapour permeability of films prepared with or without nisin were also compared. Surface hydrophobicities of WPI, SPI, egg albumen and wheat gluten were determined as 446, 282, 232 and 142, respectively. As the nisin concentration increased, the amount of inhibition progressively increased in all tested films. Using nisin, edible films with higher hydrophobicity values of 280 to 450 units under an acidic environment exerted a greater inhibitory effect against L. monocytogenes.

$\mathrm{Ku}$ et al., (2007) formulated edible films of gelatin and corn Zein by incorporating nisin to the film-forming solutions. Corn Zein film 
with nisin of 12,000 IU/ml had an increase of 11.6 $\mathrm{MPa}$ in tensile strength compared with the control, whereas gelatin film had a slight increase with the increase of nisin concentration added. Water vapour permeability for both corn Zein and gelatin films decreased with the increase of nisin concentration. Antimicrobial activity against Listeria monocytogenes increased with the increase of nisin concentration, resulting in $1.4 \log$ cycle reduction for corn Zein film and $0.6 \mathrm{log}$ cycle reduction for gelatin film at $12,000 \mathrm{IU} / \mathrm{ml}$.

\section{Starch based biodegradable films}

Starch is one of the most common and easily obtained natural polymers, making it attractive as a potential bio-based alternative to synthetic polymers. The plasticisation of starch is complex due to the extensive hydrogen bonding between chains (Abdorreza et al., 2011). This study shows that a simple quaternary ammonium salt combined with hydrogen bond donor (HBD) forms effective modifiers that produce flexible plastics with good mechanical properties that are comparable to some polyolefin plastics. Starch-based plastics can be formed by the same processes as current commercial plastics, giving similar mechanical strength to some polyolefin plastics. The processing conditions are shown to significantly affect the structure of the polymer, which has a concomitant effect upon the mechanical and physical properties of the resulting plastic. Using a glycerol based modifier results in a totally sustainable and biodegradable material which can be formed by extrusion, pressing, vacuum forming and injection moulding. Most significantly, it is shown that these plastics are environmentally compatible, recyclable, bio-degradable and compostable. Starch and cellulose are two of the most abundant polysaccharides, and both are homoglycan polymers. D-glucose is the monomer unit in both starch and cellulose; however, they have very different mechanical and chemical properties from each other due to a small difference in their structure. Starch is made up mostly of amylose and amylopectin (Avella et al., 2005). The linking oxygen atom is in the axial position, which helps all monomer glucose units to be oriented as each other, indicating that polysaccharide starch is connected by $\alpha$ (1-4) glycosidic linkage, consequently the starch chains interact in a helix. Amylopectin is a branched version of amylose, where $\alpha$ (1-6) glycosidic linkage form a branch. The glycoside linkages begin to breakdown at $150^{\circ} \mathrm{C}$ while its granules start to decompose above $250^{\circ} \mathrm{C}$. A slight degree of reorganisation of hydrogen bonds arises at low temperatures which straightens the polymer chains. The ratios and distributions of amylose and amylopectin vary in each starch depending on its source.

\section{Plasticizers}

Plasticizers are non-volatile organic molecules that are added to polymers to reduce brittleness and crystallinity, improve toughness and flexibility, lower glass transition and melting temperatures (Mekonnen et al., 2013). The council of the IUPAC (International Union of Pure and Applied Chemists) defined a plasticizer as " a substance or material incorporated in a formulation (usually a plastic or elastomer) to increase its flexibility, workability, or distensibility'. The compatibility between polymer and plasticizer is a major effective part of plasticization and various parameters including polarity, hydrogen bonding, dielectric constant and solubility parameters (Devlieghere et al., 2004). There are two types of plasticization: internal and external. Internal plasticizers chemically modify a protein chain through addition of substituent group which is attached by covalent bonds. 
Internal plasticizers create steric hindrance between the protein chains leading to increased free volume and improved flexibility. External plasticizers solvate and lubricate the protein chains, lowering the glass transition temperature of the proteins and increase the free volume. Common plasticizers used in edible films and coatings are typically polyols including glycerol, propylene glycol, polypropylene glycol, sorbitol and sucrose. Fatty acids have also been used as plasticizers in edible films and coatings. The effectiveness of a plasticizer is dependent upon: size, shape and compatibility with the protein matrix (Sothornvit and Krochta, 2001). McHugh and Krochta (1997) reported that the addition of a plasticizer increased the permeability of a film or coating. The glycerol found naturally in the combined form as glycerides in animal and vegetable fats and oils, is the best plasticizer for water soluble polymers (Muller et al., 2008). The hydroxyl groups present in glycerol are responsible for inter and intramolecular interactions in polymeric chains, providing films with a more flexible structure and adjusting them to the packaging production process (Souza et al., 2012).

Diverse physicochemical properties of plasticizers effect both mechanical and barrier properties of starch films. The addition of ampiphilic plasticizer like fatty acids (palmitic acid and stearic acid) was found to promote the development of polysacchridelipid sandwich structures in the films.

\section{Essential oils}

Essential oils (EOs) are aromatic and volatile oily extracts obtained from aromatic and medicinal plant materials, including flowers, buds, roots, bark, and leaves by means of expression, fermentation, extraction or steam distillation. Approximately 300 EOs are commercially important in the flavour and fragrance markets Van de Braak and Leijten (1999). Due to their biological properties and flavour characteristics, these oils have been extensively used for centuries in food products. Regarding the meat and meat products, EOs from oregano, rosemary, thyme, clove, balm, ginger, basilica, coriander, marjoram, lemongrass and cinnamon have shown a greater potential to be used as an antimicrobial agent. Besides antibacterial properties (Mourey and Canillac, 2002), EOs or their components have been shown to exhibit antiviral (Bishop, 1995), antimycotic (Mari et al., 2003), antitoxigenic (Juglal et al., 2002), antiparasitic (Pessoa et al., 2002), and insecticidal (Karpouhtsis et al., 1998) properties.

The use of essential oils as natural antimicrobial compounds in foods has attracted growing interest in the recent years, to meet the consumer's requirements in terms of food quality and safety. The antimicrobial activities of different essential oils and essential oil components have already been proved on different species of microorganisms (Di Pasqua et al., 2007), nevertheless, direct incorporation of essential oils in food still encounters technological limitations, related to the hydrophobic, reactive and volatile nature of the bioactive molecules constituting the essential oils (Baratta et al., 1998). EOs have been found to possess potent antibacterial and antifungal activity against several microorganisms associated with meat, including Gram positive and Gram negative bacteria. Generally they consist of more than 60 organic compounds with low molecular weight and large differences in antimicrobial capacity. The major active components of essential oils can be classified in three classes, namely phenols, terpenes, and aldehydes (Ceylan and Fung, 2004). Several works reported that all three classes of components principally act against the cell cytoplasmic membrane (Ceylan and 
Fung, 2004), especially because of their hydrophobic nature, which can affect the percentage of unsaturated fatty acid on the membrane and thus alter its structure.

\section{Lemongrass oil}

The genus Cymbopogon possesses a large number of odoriferous species of the grass family (Poaceae) and is characterized by plants bearing aromatic essential oils in all parts (EI-Kamali et al., 1998). All the grasses were first categorized under Androgopon and only five species were recognized. Out of total 30 taxa reported from Indian subcontinent, currently we have 21 taxa in India and majority of Cymbopogon species can be distinguished from the related genera by the aromatic smell.

Lemongrass is widely used in traditional medicine in many countries. Among its attributable popular properties are those related to analgesic and anti-inflammatory actions (Ortiz et al., 2002). Besides the medicinal use, the lemongrass essential oil is also used in the food (flavouring), perfume and cosmetics industries (Thapa et al., 1971). Lemongrass oil is reported to have potent antimicrobial action against number of organisms. The oil obtained from the $C$. citratus leaves exhibited antimicrobial activity when tested against 42 microorganisms (20 bacteria, 7 yeasts and 15 fungi) (Chalchat et al., 1997). The isolated bacteria presented a superior susceptibility compared to the fungi (Ibrahim, 1992). This plant extracts and/or essential oil, especially the oil for its citral content, presented positive antibacterial activity for Escherichia coli (Ogulana et al., 1987). The antioxidant activity of lemongrass oil has also been highlighted in many studies (Baratta et al., 1998) registered that the lemon grass oil had shown anti-oxidizing capacity comparable to that of tocopherol and butylated hydroxyl toluene (BHT) (Cheah et al., 2001) reported that the dichloromethane and methanolic extracts of this plant showed powerful antioxidant activity.

\section{Cinnamon oil}

For thousands of years, cinnamon has been used in spices for culinary uses. Cinnamon (Cinnamomum zeylanicum Nees), the evergreen tree of tropical area, a member of family Lauraceae, has been used in day to day routine as a spice and condiment in India.

The main compounds isolated and identified in cinnamon ( $C$. zeylanicum) belong to two chemical classes: polyphenols and volatile phenols. Among polyphenols, cinnamon contains mainly vanillic, caffeic, gallic, protocatechuic, p-coumaric, and ferulic acids (Muchuweti et al., 2007). The chemical composition of cinnamon oil depends upon the part of plant from which they are extracted. Cinnamaldehyde, is the most represented compound present in bark essential oil ranging from $62-90 \%$, depending upon extraction protocol followed (Ravishankar et al., 2009).

In cinnamon leaf essential oil, the main component is eugenol, which reaches a concentration of more than $80 \%$. Cinnamon oil in general has got good anti-inflammatory, antioxidant, anti-ulcer, anti-microbial, hypoglycemic and hypolipidemic potential. Hili et al., (1997) indicated that cinnamon oils have potential action against various bacteria (Pseudomonas aeruginosa, Staphylococcus aureus, and Escherichia coli) and yeast (Torulopsisutilis, Schizosaccharomyces pombe, Candida albicans, and Saccharomyces cerevisiae). Mathew and Abraham (2006) have reported that methanolic extract of Cinnamon contains a number of antioxidant compounds, which can effectively scavenge reactive oxygen species 
including superoxide anions and hydroxyl radicals as well as other free radicals under in vitro conditions.

Dussault et al., (2014) reported that essential oil obtained from the bark of $C$. cassia can control the growth of the spoilage microorganism L. monocytogenes in meat products contaminated at a concentration of 5 ppm, which did not change the sensorial properties of the products. In particular, cinnamon essential oil reduces the bacterial growth rate significantly in artificially contaminated samples when compared with an untreated control. Commercial essential oils obtained from the two most common species of cinnamon, C. cassia (leaf-branch) and $C$. verum (bark), were tested against $L$. monocytogenes NCTC 11994, L. monocytogenes S0580, S. typhimurium ATCC 14028, S. typhimurium S0584.

\section{Peppermint oil}

Peppermint oil is obtained from the leaves of the perennial herb, Menthapiperita L. and $M$. arvensis a member of the Labiatae family. It is a colourless, pale yellow or pale greenish yellow liquid having characteristic odour and taste followed by sensation of cold, freely soluble in ethanol (70\%). The oil is found under sides of the leaves, is extracted by steam distillation (Alankar, 2009).

Peppermint oil is commonly used as flavouring in food and beverages and as a fragrance in soaps and cosmetics. Peppermint oil may cause side effects such as heartburn and it may interact with certain medications. Peppermint oil capsules may help to relieve common symptoms of irritable bowel syndrome such as abdominal pain, bloating and gas (Zivanovic, 2005). Peppermint was first described in 1753 by Carl Linnaeus from specimens that had been collected in England; He treated it as a species (Khanna et al.,
2014) but it is now universally agreed to be a hybrid (Hoffmann and Lunder, 1984). They are dark green with reddish veins. The leaves and stems are usually slightly fuzzy. Peppermint typically occurs in moist habitats including stream sides and drainage ditches (Neeraj et al., 2013).

Peppermint has high menthol content. The oil also contains menthone and carboxyl esters, particularly menthylacetate (Burt, 2004). Dried peppermint typically has $0.3 \%-0.4 \%$ of volatile oil containing methanol (7\%-48\%), menthone (20\%-46\%), menthyl acetate (3\%$10 \%)$. Peppermint also contains small amount of many additional compounds including limane, pulegone, caryophyllene and pinene. Peppermint contains terpenoids and flavonoids such as eriocitrin, hesperidin and kaempferol 7-O-rutinoside (Sartoratto et al., 2004).

In 2014, world production of peppermint was 92, 296 tonnes, led by Morocco with 92\% of the world total reported by FAOSTAT of the United Nations. Peppermint is commonly available as an herbal supplement, there are no established, consistent manufacturing standards for it and some peppermint products may be contaminated with toxic metals or other substituted compounds.

\section{Clove oil}

Cloves are a dark brown, aromatic spice that can add an interesting flavor to food and drinks. A chemical called eugenol make up 70 to $90 \%$ of the oil and is the chief substance responsible for the aroma and taste of cloves. Cloves are the dried flower buds of the clove tree. The clove tree belongs to the myrtle family of plants. It includes the plants that produce all spice, eucalyptus oil and the bay rum oil that is used in cologne and after shave lotion. 
Clove oil has been found to have antimicrobial activity against certain harmful bacteria and yeast in food (Kouidhi et al., 2010). Eugenol is a member of phenylpropenoid class of chemical compounds. It is present in concentration of 80 to $90 \%$ in clove bud oil and at 82 to $88 \%$ is clove leaf oil (Didry et al., 1994). Eugenol is hepatoxic, meaning it may cause damage to the liver (Thompson et al., 1998). Overdose is possible, causing a wide range of symptoms from blood in the patient's urine, to diarrhoea, nausea, dizziness on rapid heartbeat (Fujiswa et al., 2002). In context, this would represent a toxic dose in a range of $500-1000 \mathrm{mg} / \mathrm{kg}$ approximately one third that of table salt (Hartnoll et al., 1993). Eugenol is a component of balsam of Peru, to which some people are allergic (Radwan et al., 2014).

For years, many dentists recommended that clove be used at home after dental procedures to disinfect open wounds and to help with any post-surgical discomfort. Today clove oils main use in dentistry is to add flavour to mouth rinse and numbering gels (Barnes et al., 2007). It is also used for its strong antioxidant content, which helps to boost the immune system and fight off infections. It's also great for eliminating fungal infections and alleviating muscle ache pains. By diffusing the oil through the air, air quality can be improved and you may benefit from the mental benefits of clove oil including improved memory, lessened anxiety and improved overall mood. The main chemical components of clove oil are eugenol, eugenol acetate, isoeugenol and caryophyllene. Clove oil is valuable for relieving respiratory problems like bronchitis, asthma and tuberculosis.

The advantage of using edible films is that, they are integral part of the food product. Edible films are in general good moisture barrier, able to inhibit moisture exchange between food product and atmosphere, preventing microbial growth, texture changes, and undesirable chemical and enzymatic reactions. It also extends the shelf life of food products.

\section{References}

Abdorreza, M.N., Cheng, L.H. and Karim, A.A. (2011). Effect of plasticizers on thermal properties and heat sealability of sago starch films. Food Hydrocolloids, 25(1):56-60.

Alankar, S. (2007). A Review on Peppermint Oil. Asian Journal of Pharmaceutical and Clinical Research, 2(2):27.

Aliabadi, S.S., Hosseini, S.M. and Mirmoghtadaie, L. (2017). Antimicrobial activity of essential oil. Essential Oil in Food Processing: Chemistry, Safety and Applications, pp191-229.

Avella, M., De Vlieger, J.J., Errico, M.E., Fischer, S., Vacca, P. and Volpe, M.J. (2005). Biodegradable starch/clay nanocomposite films for food packaging applications. Food Chemistry, 93(3):467474.

Baratta, M. T., Dorman, H. J. D., Deans, S. G., Figueiredo, A.C., Barroso, J.G. and Ruberto, G. (1998). Antimicrobial and antioxidant properties of some commercial essential oils. Flavour and Fragrance Journal, 13(4):235-244.

Biesalski, H.K., Dragsted, L.O., Elmadfa, I., Grossklaus, R., Muller, M., Schrenk, D. and Walter, P. Bioactive compounds: definition and assessment of activity. Nutrition, 25(11-12):1202-1205.

Bishop, C.D. (1995). Antiviral activity of the essential oil of Melaleuca alternifolia (Maiden and Betche) Cheel (tea tree) against tobacco mosaic virus. Journal of Essential Oil Research, 7(6):641-644.

Bourtoom, T. (2008). Edible films and coatings: Characteristics and properties. International Food Research Journal, 15(3):237-248.

Burt, S.A. (2004). Essential oils: Their antibacterial properties and potential applications in foods: a review. 
International Journal of Food Microbiology, 94:223- 253.

Cazon, P., Velazquez, G., Ramirez, A. and Vazquez, M. (2017). Polysaccharidebased films and coatings for food packaging. Food hydrocolloid, 68:136148.

Ceylan, E. and Fung, D.Y.C. (2004). Antimicrobial activity of spices. Journal of Rapid Methods and Automation in Microbiology, 12:1-55.

Chalchat, J.C., Garry, R.P., Menut, C., Lamaty, G., Malhuret, R. and Chopineau, J. (1997). Correlation between chemical composition and antimicrobial activity. VI. Activity of some African essential oils. Journal of Essential Oil Research, 9(1):67-75.

Cheah, P.B., Ng, C.H. and Wong, C.F. (2001). Antioxidant activity of tropical lemon grass (Cymbopogoncitratus) extracts in linoleic acid and chicken fat systems. Journal of Food Science and Technology, 38(1):62-64.

Choi, Y; Jeong, H.S. and Lee, J. (2007). Antioxidant activity of methanolic extracts from some grains consumed in Korea. Food Chemistry. 103(1):130-38

Cuq, B., Gontard, N. and Guilbert, S. (1998).

Protein as Agricultural Polymers for Packaging Production. Cereal Chemistry, 75(1):1-9.

Devlieghere, F., Vermerien, L. and Debevere, J. (2004). New preservation technologies: possibilities and limitations. International Dairy Journal. 14:273-85.

Di Pasqua, R., Betts, G., Hoskins, N., Edwards, M., Ercolini, D. and Mauriello, G. (2007). Membrane toxicity of antimicrobial compounds from essential oils. Journal of Agriculture and Food Chemistry, 55:4863-70.

Didry, N., Dubreuil, L., Pinkas, M. (1994) Activity of thymol, carvacrol, cinnamaldehyde and eugenol on oral bacteria. Pharmaceutica Acta Helvetiae, 69(1):25-28.

Dos Santos, N.S.T., Aguiar, A.J.A.A., De Oliveira, C.E.V., De Sales, C.V., De Melo e Silva, S., Da Silva, R.S., Stamford, T.C.M. and De Souza, E.L. (2012).
Efficacy of the application of coating composed of chitosan and Origanum vulgare L. essential oil to control Rhizopus stolonifer and Aspergillus niger in grapes (Vitis labrusca L.). Food Microbiology, 32(2):345-353.

Dussault, D., Vu, K.D. and Lacroix, M. (2014). In vitro evaluation of antimicrobial activities of various commercial essential oils, oleoresin and pure compounds against food pathogens and application in ham. Meat Science, 96(1):514-20.

Goddard, J.M. and Hotchkiss, J.H. (2007). Polymer surface modification for the attachment of bioactive compounds. Progress in Polymer Science, 32(7):698-725.

Guerra, N.P., Macias, C.L., Agrasar, A.T. and Castro, L.P. (2005). Development of bioactive packging cellophane using Nisaplin as biopreservative agent. Letters in Applied Microbiology, 40(2):106-110.

Han, J.H. (2003). Antimicrobial food Packaging. In Novel Food packaging techniques. Ed. $R$. Ahvenainen, Woodhead publishing, Cambridge, UK, pp. 50-70.

Hartnoll, G., Moore, D., Douek, D. (1993). Near fatal ingestion of oil of cloves. Archives of Disease in Childhood, 69(3):392-393.

Hili, P., Evans, C.S. and Veness, R.G. (1997). Antimicrobial action of essential oils: the effect of dimethylsulphoxide on the activity of cinnamon oil. Letters in Applied Microbiology, 24(4):269-75.

Hoffmann, B.G. and Lunder, L.T. (1984). Flavonoids from Menthapiperita leaves. Planta Medicines, 50(4):361.

Ibrahim, D. (1992). Antimicrobial activity of the essential oil of local serai, Cymbopogon citratus. Journal of Bioscience and Bioengineering, 3(1-2):87-90.

Juglal, S., Govinden, R. and Odhav, B. (2002). Spice oils for the control of co occurring mycotoxin-producing fungi. Journal of Food Protection, 65(4):683-687.

Karpouhtsis, I., Pardali, E., Feggou, E., Kokkini, S., Scouras, Z.G. and MavraganiTsipidou, P. (1998). Insecticidal and genotoxic activities of oregano essential oils. Journal of Agricultural and Food Chemistry, 46:1111-1115. 
Kesster, J.J. and Fennema, O. (1986). Edible films and coatings. Food Technology, 40:47-56.

Khanna, R., MacDonald, J.K. and Levesque, B.G. (2014). Peppermint oil for the treatment of irritable bowel syndrome: a systematic review and meta-analysis. Journal of clinical gastroenterology, 48(6):505-12.

Kim, S.J. and Ustunol, Z. (2001). Thermal Properties, Heat Sealability and Seal Attributes of whey Protein Isolate/Lipid Emulsion Edible Films. Journal of Food Science, 66(7):985-990.

Ko, S., Janes, M.E., Hettiarachcy, N.S. and Johnson, M.G. (2001) Physical and chemical properties of edible films containing nisin and their action against Listeria monocytogenes. Journal of Food Science, 66(7):1006-1011.

Kouidhi, B., Zmantar, T. and Bakhrouf, A. (2010). Anticarcinogenic and Cytotoxic activity of clove essential oil (Eugenia caryophyllata) against a large number of oral pathogens. Annals of Microbiology, 60(4):599-604.

Krochta, J.M. and Mulder-Johnston, C.D. (1997). Edible and biodegradable polymer films: Challenges and Opportunities. Food Technology, 51(2):61-74.

Ku, K. and Song, B.K. (2007). Physical properties of nisin-incorporated gelatin and corn zein films and antimicrobial activity against Listeria monocytogenes. Journal of Microbiology and Biotechnology, 17(3):520-523.

Lopez-Rubio, A., Gavara, R. and Lagaron, J.M. (2006). Bioactive packaging: turning foods into healthier foods through biomaterials. Trends Food Science Technology, 17(10):567-575.

Mari, M.P., Bertolini, and Pratella, G.C. (2003). Non-conventional methods for the control of post-harvest pear diseases. Journal of Applied Microbiology, 94(5):761-766.

Mathew, S. and Abraham, B.T.E. (2006). Studies on the antioxidant activities of cinnamon (Cinnamomum verum) bark extracts, through various in vitro models. Food Chemistry, 94:520-528.

Mehyar, G.F., Al-Ismail, K., Han, J.H. and Chee, G.W. (2012). Characterization of Edible
Coatings Consisting of Pea Starch, Whey Protein Isolate and carnauba Wax and their Effects on oil Rancidity and Sensory Properties of Walnuts and Pine Nuts. Journal of Food Science, 77(2):52-59.

Mekonnen, T., Mussone, P., Khalil, H. and Bressler, D. (2013). Progress in bio-based plastics and plasticizing modifications. Journal of Materials Chemistry A, 1:13379-13398.

Mollah, M.Z.I., Akter, N., Quader, F.B., Sultana, S. and Khan, R.A. (2016). Biodegradable Colour Polymeric Film (Starch-Chitosan) Development: Characterization for Packaging Materials. Open Journal of Organic Polymer Materials, Article ID: 62688, 6(1):60988-61002.

Mourey, A. and Canillac, N. (2002). Anti-Listeria monocytogenes activity of essential oils components of conifers. Food Control, 13(4):289-292.

Muchuweti, M., Kativu, E., Mupure, C.H., Chidewe, C., Ndhlala, A.R. and Benhura, M.A.N. (2007). Phenolic composition and antioxidant properties of some spieces. American Journal of Food Technology, 2(5):414-20.

Müller, C.M.O., Yamashita, F. and Laurindo, J.B. (2008). Evaluation of the effects of glycerol and sorbitol concentration and water activity on the water barrier properties of cassava starch films through a solubility approach. Carbohydrate Polymer, 72(1):82-87.

Naik, M.I., Fomda, B.A., Jaykumar, E. and Bhat, J.A. (2010). Antimicrobial activity of lemongrass (Cymbopogon citatus) oil against some selected pathogenic bacteria. Asian Pacific Journal of Tropical Medicine, 3(7):535-538.

Nandane, A.S. and Jain, R.K. (2015). Study of mechanical properties of soy protein based edible film as affected by its composition and process parameters by using RSM. Journal Food Science Technology, 52(6):3645-3650.

Neeraj, T., Prakash, A. and Seema, Yadav. (2013). Antimicrobial Activity and Medicinal Values of Essential Oil of Mentha piperita L. International Journal of Engineering and Innovative 
Technology, 2(8):214-218.

NurHanani, Z.A., Roos, Y.H. and Kerry, J.P. (2014). Use and application of gelatin as potential biodegradable packaging materials for food products. International Journal of Biological Macromolecules, 71:94-102.

Ogunlana, E.O., Höglund, S., Onawunmi, G. and Sköld, O. (1987). Effects of lemongrass oil on the morphological characteristics and peptidoglycan synthesis of Escherichia coli cells. Microbios, 50(202):43-59.

Ortiz, R.S., Marrero, G.V. and Navarro, A.L.T. (2002). Instructivotécnicodelcultivo de Cymbopogoncitratus (D.C) Stapf (Cañasanta). Revista de PlantasMedicinales, 7(2):89-95.

Ou, L.C., Luo, M.R., Woodcock, A. and Wright, A. (2004). A study of colour emotion and colour preference. Part 1: Colour emotions for single colours. Colour research and applications, 29(3):232-240.

Perez-Perez, C., Regolado-Gonzales, C., Rodriquez-Rodriquez, C.A., BarbosaRoderiquez, J.R. and Villasenor-Ortega, F. (2006). Incorporation of antimicrobial agents in food packaging films and coatings. In: Guevara- Gonzales $R G$, Torres-Pacheco I (eds) Advances in Agricultural and Food Biotechnology. Research Signpost, Trivandrum, pp193216.

Pessoa, L.M., Morais, S.M., Bevilaqua, C.M.L. and Luciano, J.H.S. (2002). Anthelmintic activity of essential oil of Ocimum gratissimum Linn. And eugenol against Haemonchus contortus. Veterinary Parasitology, 109(1-2):59-63.

Pranoto, Y., Rakshit, S.K. and Salokhe, V.M. (2005). Enhancing antimicrobial activity of chitosan films by incorporating garlic oil, potassium sorbate and nisin. Food Science and Technology, 38:859-865.

Pranoto; Yudi; Rakshi; Sudip; Salokhe and Vilas (2005). Enhancing antimicrobial activity of chitosan films by incorporating garlic oil, potassium sorbate and nisin. Food Science and Technology, 38:859-865.

Radwan, I.A., Abed, A.H., Abeer, M.R., Ibrahim, M.A. and Abdallah, A.S. (2014). Effect of
Thyme, Clove and Cinnamon Essential Oils on Candida albicans and Moulds Isolated from different Sources. American Journal of Animal and Veterinary Sciences, 9(4):303-314.

Ravishankar, S., Zhu, L., Olsen, C.W., Mchugh, T.H. and Friedman, M. (2009). Edible Apple Film Wraps Containing Plant Antimicrobials Inactivate Foodborne Pathogens on Meat and Poultry Products. Journal of Food Science, 74(8):440-45.

Rhim, J.W. and Shellhammer, T.H. (2005). LipidBased edible films and coatings. Innovations in Food Packaging, pp362383.

Romanazi, G., Nigro, F., Ippolito, A.: Venere, D.D. and Salemo, M. (2002). Effect of pre and postharvested chitosan treatments to control storage grey mold of table grapes. Journal of Food Science, 67(5):1862-1867.

Sartoratto, A.L.M., Machado, C., Delarmelina, G.M., Figueira, M.C.T., Duarte, V.L.G. (2004). Composition and antimicrobial activity of essential oils from aromatic plants used in Brazil. Braz. Journal of Microbiology, 34(4):1517-1520.

Singh, P.T., Chatli, M.K. and Sahoo, J. (2015). Development of chitosen based edible films: process optimization using response surface methodology. Journal of Food Science Technology, 52(5):25302543.

Singh, R. (2015). Antimicrobial and antioxidant activities of Menthapiperita L. Arabian Journal of Chemistry, 8(3):322-328.

Snedecor, G. W. and Cochran, W. G. (1994). Statistical Methods, $8^{\text {th }}$ edition. Journal of Educational and Behavioural Statistics, 19(3):304-307.

Sobral, P., De Alvarado, J.D., Zaritzky, N.E., Laurindo, J.B., Gomez-Guillen, C., Anon, M.C., Montero, P., Denavi, G., Molina Ortiz, S., Mauri, A., Pinotti, A., Garcia, M., Martino, M.N. and Carvalho, R. (2005). Films Based on Biopolymer from Conventional and Non-Conventional Sources. Food Engineering: Integrated Approaches, Food Engineering Series, Springer, New York, NY, pp193-223.

Sobral, P.J.D.A., Dos Santos, J.S. and Garcia, 
F.T. (2004). Effect of protein and plasticizer concentrations in film forming solutions on physical properties of edible films based on muscle proteins of a Thai Tilapia. Journal of Food Engineering, 70:93-100.

Sothornvit, R. and Karochta, J.M. (2001). Plasticizer effect on mechanical properties of $\beta$-lactoglobulin films. Journal of Food Engineering, 50(3):02608774.

Souza, A.C., Benze, R., Ferrao, E.S., Ditchfield, C., Coelho, A.C.V. and Tadini, C.C. (2012). Cassava starch biodegradable films: Influence of glycerol and clay nanoparticles content and tensile and barrier properties and glass transition temperature. LWT- Food Science and Technology, 46(1):110-117.

Su, Guocheng., Cai, H., Zhou, C. and Wnag, Z. (2007). Formulation of Edible Soybean films. Food Technology and Biotechnology, 45(4): 381-388.

Talja, R. A. (2007). Preparation and Characterization of potato starch films plasticized with polyols. University of Helsinki, Department of Food Technology, 1-65.

Thapa, R.K., Bradu, B.L., Vashist, V.N. and Atal, C.K. (1971). Screening of Cymbopogon species for useful constituents. Flavour Industry, 2:49-51.

Thompson, D.C., Barhoumi, R., Burghardt, R.C. (1998). Comparative toxicity of eugenol and its quinonemethide metabolite in cultured liver cells using kinetic fluorescence bioassays. Toxicology and Applied Pharmacology, 149(1):55-63.

Trout, E. S., Hunt, N. C., Johnson, D. E., Claus, J. R., Kashner, C. L. and Krolpf, O. H. (1992). Chemical, physical and sensory Characteristics of ground beef containing 5-30 percent fat. Journal of Food Science, 57(1):25-29.

Trout, E.S., Hunt, M.C., Johnson, D.E., Claus, J.R., Kastner, C.L. and Kropt, D.H. (1992). Characterstics of low fat ground beef containing texture modifying ingredients. Journal of Food Science, 57:19-24.

Van de Braak, S.A.A.J. and Leijten, G.C.J.J. (1999). Essential oils and Oleoresins: A Survey in the Netherlands and other major Markets in the European Union; CBI, Centre for the promotion of Imports from Developing Countries. Rotterdam, The Netherlands, pp116.

Wagh, R.V., Chatli, M.K., Ruusunen, M., Puolanne, E. and Ertbjerg, P. (2015). Effect of various phyto-extracts on physicochemical, colour, and oxidative stability of pork frankfurters. AsianAustralasian Journal of Animal Science, 28(8):1178.

Zivanovic, S., Chi, S. and Draughon, A.F. (2005). Antimicrobial activity of chitosan films enriched with essential oils. Journal of Food Science, 7 (1):45-51.

\section{How to cite this article:}

Aashima, Prerna Singh and Anshu Sibbal Chatli. 2020. A Review on Biodegradable Films. Int.J.Curr.Microbiol.App.Sci. 9(05): 3039-3051. doi: https://doi.org/10.20546/ijcmas.2020.905.362 